\title{
Cytokine Response of CD4+ T-Lymphocytes with Red Rose (Rosa Rosaceae - Pierre de Ronsard) Extracts by in Vitro Evaluation
}

\author{
Mark Christopher Arokiaraj ${ }^{* *}$ (D), Eric Menesson ${ }^{2}$
}

\begin{abstract}
Background. Red rose extract is known to have anti-inflammatory and immune-modulation effects. In this study, the red rose extract was tested on CD4+T lymphocytes in vitro, and cytokine response was evaluated.

Materials and Methods. The red rose (Rosa Rosaceae - Pierre de Ronsard) extract used in this study was prepared and stored at $-20^{\circ} \mathrm{C}$ until use. CD4+T-cells were seeded in 96-well plates at 313,500 cells/well in $100 \mu \mathrm{l}$ cell culture medium in duplicate. One-half of the wells were used for biomarker screening in the culture medium, and the other half was used for cytotoxicity assay. Twenty-four hours after plating, the cells were treated in duplicate with $100 \mu \mathrm{l}$ of the red rose extract diluted at $0.5 \%, 0.1 \%, 0.05 \%, 0.01 \%$ and $0.005 \%(\mathrm{v} / \mathrm{v})$ in the cell culture medium or with culture medium only as control for 72 hours. Some other wells were allocated for untreated cells, and cells treated with the rose extract at $0.005 \%$ for $48-\mathrm{h}$ incubation time.

Results. Several cytokines (GRO; IFN- $\gamma$; IL- $1 \alpha, 6$, 10; MCP-1; RANTES; TGF- $\beta 1$; TIMP 1, 2; Ang1, Ang2; G-CSF; MMP-9; and VEGF R2) were elevated. Except for MMP-9, which had fold changes $>2$, other cytokines were minimally elevated at various concentrations and timing of rose extract treatment. None of the mentioned cytokines were less than 0.8 -fold after treatment with the rose extract. Cytotoxicity assay revealed insignificant changes in the viability of T-cells.

Conclusions. There was a mild elevation in few inflammatory markers by CD4+ T-lymphocytes after in vitro treatment with the red rose extract (Rosa Rosacea - Pierre De Ronsard). Further in vitro and in vivo studies are required to evaluate the benefits of the red rose extract in immune regulation.
\end{abstract}

Keywords

Inflammation; Immune Response; Rose Extract; Pierre De Ronsard; Cytokine Levels; CD4+ T-Cells

${ }^{1}$ Cardiology, Pondicherry Institute of Medical Sciences, Pondicherry, India

${ }^{2}$ Tebu Bio, Lab services, France

*Corresponding author: christomark@gmail.com

Copyright @Mark Christopher Arokiaraj, Eric Menesson, 2022

\section{Introduction}

Immune diseases are common in clinical practice $[1,2]$. The incidence of immune-related dysfunction is seen in about $7.5 \%$ to $9.5 \%$ of the population [1]. Prevalence rates range from less than 5 cases per 100,000 people (e.g., chronic active hepatitis, uveitis) to more than 500 cases per 100,000 people (Grave disease, rheumatoid arthritis, thyroiditis) [2]. In the recent years, the incidence of autoimmune disorders continues to remain high [3]. Most non-communicable diseases, malignancies and infections also have some immunological background [4]. Positive immune modulation with reducing systemic inflammation has potential advantages as a therapy [5, 6]. However, current immunomodulators could reduce lymphocyte pro- liferation $[7,8]$ and function [9] which may lead to various side-effects. Some of the side effects include susceptibility to infections [10], worsening of metabolic parameters [11, 12], renal dysfunction [13], etc. T-cells play a key role in an immune response $[14,15]$ and discovering novel immunomodulators with no side effects and proliferation reducing remains relevant. Roses are widely used in medicine [16-19], however, the effects of red rose "Pierre de Ronsard" on T-cells are not well-documented.

This study was aimed to investigate the immunomodulation effect of the red rose (Rosa Rosaceae - Pierre de Ronsard) extract on CD4+ T-cells in vitro. 


\section{Materials and Methods}

\section{CD4+T lymphocyte In Vitro Treatment}

The red rose (Rosa Rosaceae - Pierre de Ronsard) extract from the rose petals used in this study was prepared [20] and stored at $-20^{\circ} \mathrm{C}$ until use. Human peripheral blood CD4+ T-cells (Cell Applications, ref. 6902-50a, lot 3298) were seeded in 96-well plates at 313, 500 cells/well $\left(950,000\right.$ cells $\left./ \mathrm{cm}^{2}\right)$ in $100 \mu 1$ cell culture medium (Cell Applications, ref. 615-250) in duplicate, with one half of wells used for biomarkers screening in the culture medium and the other half for cytotoxicity assay. Twenty-four hours after plating, the cells were treated in duplicate with $100 \mu \mathrm{l}$ of the red rose extract diluted at $0.5 \%, 0.1 \%, 0.05 \%, 0.01 \%$ and $0.005 \%(\mathrm{v} / \mathrm{v})$ in the cell culture medium or with culture medium only as control for 72 hours. Some other wells were used for untreated cells and cells treated with the rose extract at $0.005 \%$ for 48 -h incubation time. After 48 and 72 hours, the corresponding wells were used for cytotoxicity assay and from the duplicate wells, the cell culture media were collected and stored at $-80^{\circ} \mathrm{C}$ until biomarker screening assay. Biomarker screening assay was performed with Human Angiogenesis Antibody Array G-Series 1000 from RayBio®AAH-ANG-G1000.

\section{Cytotoxicity Assay}

After 48-h incubation time, cell viability was assessed using - Cell Counting Kit-8 (Dojindo EU Gmbh, ref. CK04). The kit uses WST-8 (2-(2-methoxy-4-nitrophenyl)-3-(4nitrophenyl)-5-(2,4-disulfophenyl)-2H-tetrazolium, monosodium salt) or MTT which produces a water-soluble formazan dye upon bio-reduction in the presence of an electron carrier, 1- Methoxy PMS (phenazine methosulfate). WST-8 (10\% of the medium volume in wells) was added to the media for 4 hours at $37^{\circ} \mathrm{C}$. During the incubation time, it is bio-reduced by cellular dehydrogenases to an orange formazan product that is soluble in the culture medium. Then, the amount of formazan produced is directly proportional to the number of living cells. The absorbance of formazan was measured at $450 \mathrm{~nm}$, which enabled the calculation of viable cells percentage for each treatment compared to non-treated cells.

\section{Profiling of Secreted Cytokines}

The technique of Quantibody assay is similar to the method described in our previous studies [20]. During the incubation time, the volume of the medium varied differently in each well and the volume collected might be reduced. To normalize the profiling results, the cell culture medium was added to the different collected media to reach $200 \mu 1$ before performing profiling assay. Then, the medium samples were tested undiluted on arrays.

\section{Results}

The results of cytotoxicity assay showed there was no strong effect on the viability of T-cells even though the viability went down until $87 \%$ for cells treated for 72 hours with $0.01 \%$ red rose extract. Indeed, such a decrease in the viability in one tested replicate is not statistically representative of the cytotoxicity effect of the red rose extract. Table 1 shows the results of cytotoxicity assay.

Interferon $\gamma$ (IFN- $\gamma$ ), monocyte chemoattractant protein 1 (MCP-1), growth-regulated oncogene (GRO), regulated on activation, normal T-cell expressed and secreted (RANTES) and tissue inhibitor of metalloproteinases (TIMP), Angiopoietin-1 (Ang1) and matrix metallopeptidase 9 (MMP-9) were elevated. Except for MMP-9, which had fold changes $>2$, other cytokines were mildly elevated at various concentrations and timing of red rose extract treatment (Table 2 and 3). GRO was mainly elevated at higher $(0.5 \%)$ and lower $(0.005 \%)$ concentrations. MCP-1 and RANTES showed an increasing trend with decreasing levels of red rose extract concentrations. Interleukin 6 (IL-6) showed a higher value in higher $(0.5 \%)$ and lower dilutions $(0.005 \%)$. The results also showed that cytokines IL-6, IL-10, IL- $1 \alpha$, transforming growth factor beta 1 (TGF- $\beta 1$ ), TIMP-2, Ang2, granulocyte-colony stimulating factor (G-CSF), and vascular endothelial growth factor receptor 2 (VEGF R2) were enough detected to enable the calculation of one-fold change at least.

\section{Discussion}

Our study results showed cytokines - GRO, IFN- $\gamma$, IL-6, MCP-1, RANTES, TGF- $\beta$ 1, TIMP-1, TIMP-2, Ang1, Ang2, G-CSF, IL-10, IL-1 $\alpha$, MMP-9, and VEGF R2 were enough detected to enable the calculation of one-fold change at least.

Our previous study results of red rose extract treatment on endothelial cells showed a reduction in cytokine levels and other inflammatory markers [20]. In the clinical scenarios, it could be advantageous, i.e., a reduction in the inflammation of endothelial cells when combined with a stimulatory effect on lymphocytes, which is uniquely observed in this study. Cytotoxicity assay in this study revealed insignificant changes with minimal reduction in the viability of cells. The absence of cytotoxicity of the red

Table 1. The results of cytotoxicity assay based on absorbance observed due to orange formazan product.

\begin{tabular}{lcccc}
\hline \multirow{2}{*}{ Cell treatment } & \multicolumn{2}{c}{ 48-h incubation time } & \multicolumn{2}{c}{ 72-h incubation time } \\
& Absorbance $(450 \mathrm{~nm})$ & Untreated cells, \% & Absorbance $(450 \mathrm{~nm})$ & Untreated cells, \% \\
\hline Untreated cells & 0.758 & $100 \%$ & 0.754 & $100 \%$ \\
$0.5 \%$ rose extract & - & - & 0.813 & $108 \%$ \\
$0.1 \%$ rose extract & - & - & 0.709 & $94 \%$ \\
$0.05 \%$ red rose extract & - & - & 0.698 & $93 \%$ \\
$0.01 \%$ red rose extract & - & $96 \%$ & 0.655 & $87 \%$ \\
$0.005 \%$ red rose extract & 0.73 & 0.723 & $96 \%$ \\
\hline
\end{tabular}


Table 2. Results of secreted cytokine profiling: fold changes of treated cells vs. untreated cells at both incubation times for AAH-ANG-G1 microarray. Target not detected (-).

\begin{tabular}{|c|c|c|c|c|c|c|}
\hline & $\begin{array}{c}0.005 \% 48 \mathrm{~h} \text { vs. } \\
\text { untreated cells } \\
48 \mathrm{~h}\end{array}$ & $\begin{array}{c}0.5 \% 72 \mathrm{~h} \text { vs. } \\
\text { untreated cells } \\
72 \mathrm{~h}\end{array}$ & $\begin{array}{c}0.1 \% 72 \mathrm{~h} \text { vs. } \\
\text { untreated cells } \\
72 \mathrm{~h}\end{array}$ & $\begin{array}{c}0.05 \% 72 \mathrm{~h} \text { vs. } \\
\text { untreated cells } \\
72 \mathrm{~h}\end{array}$ & $\begin{array}{c}0.01 \% 72 \mathrm{~h} \text { vs. } \\
\text { untreated cells } \\
72 \mathrm{~h}\end{array}$ & $\begin{array}{c}0.005 \% 72 \mathrm{~h} \text { vs. } \\
\text { untreated cells } \\
72 \mathrm{~h}\end{array}$ \\
\hline Angiogenin & - & - & - & - & - & - \\
\hline EGF & - & - & - & - & - & - \\
\hline ENA-78 & - & - & - & - & - & - \\
\hline bFGF & - & - & - & - & - & - \\
\hline GRO & 0.92 & 1.84 & 1.17 & 1.05 & 1.27 & 1.61 \\
\hline IFN- $\gamma$ & 0.96 & 1.19 & 1.25 & 1.23 & 1.15 & 1.21 \\
\hline IGF-I & - & - & - & - & - & - \\
\hline IL-6 & 0.96 & 1.55 & 1.12 & 1.12 & 1.13 & 1.21 \\
\hline IL-8 & - & - & - & - & - & - \\
\hline Leptin & - & - & - & - & - & - \\
\hline MCP-1 & 1.12 & 1.08 & 1.33 & 1.08 & 1.39 & 1.75 \\
\hline PDGF-BB & - & - & - & - & - & - \\
\hline PIGF & - & - & - & - & - & - \\
\hline RANTES & 0.92 & - & 0.8 & 1.14 & 1.45 & 1.63 \\
\hline TGF- $\beta 1$ & 0.93 & 1.05 & 1.07 & 0.97 & 1.01 & 1.13 \\
\hline TIMP-1 & 0.84 & 1.04 & 1.24 & 1.04 & 1.11 & 1.23 \\
\hline TIMP-2 & - & - & 1.2 & - & 1.05 & 1.16 \\
\hline Thrombopoietin & - & - & - & - & - & - \\
\hline VEGF & - & - & - & - & - & - \\
\hline VEGF-D & - & - & - & - & - & - \\
\hline
\end{tabular}

Table 3. Results of secreted cytokine profiling: fold changes of treated cells vs. untreated cells at both incubation times for AAH-ANG-G2 microarray. Target not detected (-).

\begin{tabular}{|c|c|c|c|c|c|c|}
\hline & $\begin{array}{c}0.005 \% 48 \mathrm{~h} \text { vs. } \\
\text { untreated cells } \\
48 \mathrm{~h}\end{array}$ & $\begin{array}{c}0.5 \% 72 \mathrm{~h} \text { vs. } \\
\text { untreated cells } \\
72 \mathrm{~h}\end{array}$ & $\begin{array}{c}0.1 \% 72 \mathrm{~h} \text { vs. } \\
\text { untreated cells } \\
72 \mathrm{~h}\end{array}$ & $\begin{array}{c}0.05 \% 72 \mathrm{~h} \text { vs. } \\
\text { untreated cells } \\
72 \mathrm{~h}\end{array}$ & $\begin{array}{c}0.01 \% 72 \mathrm{~h} \text { vs. } \\
\text { untreated cells } \\
72 \mathrm{~h}\end{array}$ & $\begin{array}{c}0.005 \% 72 \mathrm{~h} \text { vs. } \\
\text { untreated cells } \\
72 \mathrm{~h}\end{array}$ \\
\hline Ang1 & 0.72 & 0.69 & 1.3 & 1.29 & 1.35 & 1.18 \\
\hline Ang2 & 0.68 & 0.94 & 1.01 & 1.05 & 0.92 & 0.79 \\
\hline Angiostatin & - & - & - & - & - & - \\
\hline Endostatin & - & - & - & - & - & - \\
\hline G-CSF & 1.04 & - & - & - & - & - \\
\hline GM-CSF & - & - & - & - & - & - \\
\hline I-309 & - & - & - & - & - & - \\
\hline IL-10 & 1.14 & - & - & - & - & 0.94 \\
\hline IL-1 $\alpha$ & 1.05 & 1.17 & 1.09 & 1 & 0.96 & 0.93 \\
\hline IL-1 $\beta$ & - & - & - & - & - & - \\
\hline IL-2 & - & - & - & - & - & - \\
\hline IL-4 & - & - & - & - & - & - \\
\hline I-TAC & - & - & - & - & - & - \\
\hline MCP-3 & - & - & - & - & - & - \\
\hline MCP-4 & - & - & - & - & - & - \\
\hline MMP-1 & - & - & - & - & - & - \\
\hline MMP-9 & - & 2.68 & 1.81 & 1.71 & 2.62 & 2.23 \\
\hline PECAM-1 & - & - & - & - & - & - \\
\hline Tie-2 & - & - & - & - & - & - \\
\hline TNF- $\alpha$ & - & - & - & - & - & - \\
\hline u PAR & - & - & - & - & - & - \\
\hline VEGF R2 & 0.98 & 1.13 & 1.08 & 0.96 & 0.93 & 0.84 \\
\hline VEGF R3 & - & - & - & - & - & - \\
\hline
\end{tabular}


rose extract, even in higher concentrations, has potential advantages to evolve as a therapy in the future. However, the results observed are preliminary and need further evaluation in vitro.

MMP-9 is involved in vascular remodeling of angiogenesis, wound repair, and neutrophil migration across the basement membrane [21, 22]. It is also regulated alongside with VEGF in angiogenesis, especially with hypoxia as a trigger [24-29]. At the same time, Ang1 is involved as the master regulator of angiogenesis [30, 31]. Das A. et al. [23] and Nowicki M. et al. [26] have found that angiopoietins increase MMP-9 and are closely regulated in the angiogenesis process. In our study, Ang1 was mildly elevated, especially in treatment with lower concentrations of the red rose extract $-0.05,0.01$, and 0.005 percent by $1.29,1.35$, and 1.18 times, respectively after 72 hours of treatment and together with increase in MMP-9 (1.71 - 2.68 times depending on the concentration), probably will have a superior influence of red rose extracts on angiogenesis. On other hand, TIMP-2 regulates MMP-9, and their balance is important for cells proliferation controlling [32]. Our study showed mild elevation of TIMP-2 accompanied with high elevation of MMP-9. These results confirm that the red rose extract does not affect balance between TIMP-2 and MMP-9. TGF- $\beta 1$ plays a role of immunosuppressive cytokine through the inhibition of Tcell proliferation [33]. However, its level reduced after treatment with $0.005 \%(48 \mathrm{~h})$ and $0.05 \%(72 \mathrm{~h})$ extract and mildly elevated (1.01-1.13) in case of 72-h treatment with $0.005 \%, 0.01 \%, 0.1 \%$ and $0.5 \%$ concentrations.

A broad spectrum of cytokines is involved in the inflammation process. Thus, IFN- $\gamma$ plays a key role in immune functions [34]; RANTES [37] and TIMP-1 [38] are inflammatory mediators in acute and chronic inflammation; MCP-1 [35] and GRO [36] are chemotactic cytokines, especially for mononuclear cells. These inflammatory markers (IFN- $\gamma$, MCP-1, GRO, RANTES, and TIMP-1) were observed to be elevated in this study and confirmed immunomodulation effect of the red rose extract on T-lymphocytes. Contrarily, these cytokines were reduced as compared to the controls in endothelial cells [20]. IL6, IL10, and IL1 $\alpha$ serve as major regulators in immune responses and inflammation [39-41]. At the same time, inflammation and angiogenesis processes involve Ang2 [42] and VEGF R2 [43] as well. In our study, IL-6 was mildly elevated, IL-10 and IL-1 $\alpha$ levels did not change significantly (Table 2 and 3). However, treatment of T-cells with the red rose extract at concentrations of 0.01 and $0.005 \%$ for 72 hours showed mild reducing in Ang2 and VEGF R2. G-CSF has a role in granulopoiesis and anti-inflammation [44], however, it was mildly increasing (1.04) after 48 hours of treatment with $0.005 \%$ red rose extract.

Meanwhile, it is an important question of advantages or disadvantages of the red rose extract in comparison with other rose extracts/ingredients with immunomodulation effects [45-54]. Thus, the effect of Rose odorata was studied in the RAW 264.7 cell/monocyte-macrophage cell line, and reducing in TNF- $\alpha$, IL-6, IL-1 $\beta$ was found [45]. Gruenwald $\mathrm{J}$ et al., according to the systematic review re- sults, have concluded that the ingredients of Rosa canina reduce inflammatory markers and cytokines in vivo [46]. Immunomodulation activity of Kushui Rose (Rosa setate $x$ Rosa rugosa) was studied as well $[47,51]$. It was found that WSRP-1 $\beta$ - a novel polysaccharide from Kushui Rose - has immunomodulatory activity by enhancing phagocytosis of macrophages, increasing production of reactive oxygen species (ROS), nitric oxide (NO), cytokines (IL-6, $\mathrm{TNF}-\alpha)$, and activating nuclear factor kappa B (NF- $\kappa \mathrm{B})$ signaling pathway [47]. The results of our study showed immunomodulation potency of Rosa Rosaceae as well, as evidenced by elevation of MMP9, GRO, IFN- $\gamma$, MCP-1, TIMP-1 and TIMP-2 (Table 2, 3). Al-Oqail M et al. found cytotoxicity effect of Rosa damascena in cervical cancer HeLa cells [48]. In our study, IL-6 and IFN- $\gamma$ were mildly elevated, but there were no changes in IL-10, TNF- $\alpha$, and GM-CSF (Table 2, 3); cytotoxicity of the rose extract (Pierre de Ronsard) on CD4+ T lymphocytes by MTT assay was negligible.

Blossom and bee pollen from Rosa rugosa had effects of decreasing triglyceride (TG) levels in the sebaceous glands, decreasing the release of IL- $1 \alpha$ and TNF- $\alpha$, alleviating the release of MMP-2 and MMP-9, increasing the content of caspase-3, reducing the release of testosterone $\mathrm{T}$, and increasing the release of estrogen $\mathrm{E}_{2}$ [49]. Similarly, Rosa webbiana reduces TNF- $\alpha$ and NF- $\kappa \mathrm{B}$, which in fact can have antiepileptic, anti-apoptotic, and neuroprotective potentials [50]. Our study on T-cells showed that the red rose extract increased IL- $1 \alpha$ levels, however, TNF- $\alpha$ levels were not changed.

Rugosic acid derived from $R$. rugosa has been shown to reduce NF- $\kappa$ B and the IL- $6 /$ signal transducer and activator of transcription 3 (STAT3) axis in the acute lung injury model [52]. STAT3 is a critical signaling molecule that is involved in the formation of the tumor microenvironment through regulating downstream proinflammatory cytokines and factors promoting tumor growth, progression, and metastasis [53]. In our study, IL-6 was elevated, but the exact significance on the STAT3 axis needs to be evaluated by future studies in this context. Rosa laevigata extract has shown suppression effect of immunoglobulin E ( $\mathrm{IgE}$ ) and related cytokines in in vitro and in vivo model of allergic asthma [54]. IgE-associated cytokines like IL-5 and IL-13 were not studied in our study, whereas IL-4 levels were not changed with red rose extract treatment.

\section{Limitations}

This study is performed in vitro. Further extensive evaluation of the extract needs to be performed in the animal models, and the side-effect profile of the extract needs to be evaluated as well. The pharmacological activity, mechanism of action and chemical content of the Rosa Rosaceae (Pierre De Ronsard) extract should be evaluated in detail. In addition, the feedback response mechanism, which could exist in T-cells in the immune regulation process, needs to be studied in vivo.

\section{Conclusions}

In this study, red rose (Rosa Rosaceae - Pierre de Ronsard) extract treatment on CD4+ T-lymphocytes showed mildly 
increased cytokines - GRO, IFN- $\gamma$, IL-6, MCP-1, RANTES, TGF- $\beta$ 1, TIMP-1, TIMP-2, Ang1, Ang2, G-CSF, IL-10, IL-1 $\alpha$, MMP-9 and VEGF R2 by at-least one-fold change. There was no significant fold change over 2 or lower 0.5 , except for MMP-9 with a fold change, often $>2$. A significant fold change variation between different concentrations of investigated extract and untreated cells were observed in RANTES levels, and to a lesser extent in MCP-1, IL-1 $\alpha$, and VEGF R2. Further studies are required to evaluate the actions of the red rose extract in vitro and in vivo.

\section{Ethical Statement}

No approval of local ethics committee was required to accomplish the goals of this study.

\section{Conflict of Interest}

The authors declare that no conflicts exist.

\section{Financial Disclosure}

The authors declared no financial support.

\section{References}

[1] Cooper GS, Bynum MLK, Somers EC. Recent insights in the epidemiology of autoimmune diseases: Improved prevalence estimates and understanding of clustering of diseases. Journal of Autoimmunity. 2009;33(3-4):197-207. Available from: https://doi.org/10.1016/j.jaut.2009.09.008

[2] Cooper GS, Stroehla BC. The epidemiology of autoimmune diseases. Autoimmunity Reviews. 2003;2(3):119-125. Available from: https://doi.org/10.1016/S1568-9972(03)00006-5

[3] Willame C, Dodd C, van der Aa L, Picelli G, Emborg H-D, Kahlert $\mathrm{J}$, et al. Incidence rates of autoimmune diseases in european healthcare databases: a contribution of the ADVANCE project. Drug Safety. 2021;44(3):383-395. Available from: https://doi.org/10.1007/s40264-020-01031-1

[4] Bagatini MD, Cardoso AM, Reschke CR, Carvalho FB. Immune system and chronic diseases 2018. Journal of Immunology Research. 2018;2018:1-2. Available from: https://doi.org/10.1155/2018/8653572

[5] Nediani C, Giovannelli L. Oxidative stress and inflammation as targets for novel preventive and therapeutic approches in non communicable diseases. Antioxidants. 2020;9(4):290. Available from: https://doi.org/10.3390/antiox9040290

[6] Duan L, Rao X, Sigdel KR. Regulation of inflammation in autoimmune disease. Journal of Immunology Research. 2019;2019:1-2. Available from: https://doi.org/10.1155/2019/7403796

[7] Ménétrier-Caux C, Ray-Coquard I, Blay J-Y, Caux C. Lymphopenia in cancer patients and its effects on response to immunotherapy: an opportunity for combination with cytokines? Journal for ImmunoTherapy of Cancer. 2019;7(1):85. Available from: https://doi.org/10.1186/s40425-019-0549-5
[8] P Abraham B, H Sellin J. Lymphopenia in inflammatory bowel disease patients on immunosuppressive medications. Journal of Gastroenterology and Hepatology Research. 2016;5(1):1890-1894. Available from: https://doi.org/10.17554/j.issn.22243992.2016.05.595

[9] Xia A, Zhang Y, Xu J, Yin T, Lu X-J. T cell dysfunction in cancer immunity and immunotherapy. Frontiers in Immunology. 2019;10:1719. Available from: https://doi.org/10.3389/fimmu.2019.01719

[10] Bascones-Martinez A, Mattila R, Gomez-Font R, Meurman J. Immunomodulatory drugs: oral and systemic adverse effects. Medicina Oral Patología Oral y Cirugia Bucal. 2014;19(1):e24-e31. Available from: https://doi.org/10.4317/medoral.19087

[11] Bamgbola O. Metabolic consequences of modern immunosuppressive agents in solid organ transplantation. Therapeutic Advances in Endocrinology and Metabolism. 2016;7(3):110-127. Available from: https://doi.org/10.1177/2042018816641580

[12] Claes K, Meier-Kriesche H-U, Schold JD, Vanrenterghem Y, Halloran PF, Ekberg H. Effect of different immunosuppressive regimens on the evolution of distinct metabolic parameters: evidence from the Symphony study. Nephrology Dialysis Transplantation. 2011;27(2):850-857. Available from: https://doi.org/10.1093/ndt/gfr238

[13] Salama AD. Chapter 6 Renal toxicities associated with immunomodulatory drugs. the kidney in systemic autoimmune diseases. 2007;7:107-119. Available from: https://doi.org/10.1016/S1571-5078(07)07006-7

[14] Luckheeram RV, Zhou R, Verma AD, Xia B. CD4+T cells: differentiation and functions. Clinical and Developmental Immunology. 2012;2012:1-12. Available from: https://doi.org/10.1155/2012/925135

[15] Kumari J, Selvan SR, Becart S, Chattopadhyay S, Dalmo RA. Cell-mediated immunity and vaccines. Journal of Immunology Research. 2014;2014:1-2. Available from: https://doi.org/10.1155/2014/632632

[16] Jahromi HK, Jashni HK, Dialemeh S. Effect of Damask Rose extract on FSH, LH and testosterone hormones in rats. Int $\mathrm{J}$ Med Res Health Sci. 2016;5(S):267-271. Available from: https://www.ijmrhs.com/medical-research/effectof-damask-rose-extract-on-fsh-lh-and-testosteronehormones-in-rats.pdf

[17] Akram M, Riaz M, Munir N, Akhter N, Zafar S, Jabeen F, et al. Chemical constituents, experimental and clinical pharmacology of Rosa damascena: a literature review. Journal of Pharmacy and Pharmacology. 2019;72(2):161-174. Available from: https://doi.org/10.1111/jphp.13185 
[18] Mohebitabar S, Shirazi M, Bioos S, Rahimi R, Malekshahi F, Nejatbakhsh F. Therapeutic efficacy of rose oil: a comprehensive review of clinical evidence. Avicenna J Phytomed. 2017;7(3):206-213. Available from: https://www.ncbi.nlm.nih.gov/pmc/articles/PMC5511972/

[19] Hamidpour R, Hamidpour S, Hamidpour M, Marshall V, Hamidpour R. Pelargonium graveolens (Rose geranium) - a novel therapeutic agent for antibacterial, antioxidant, antifungal and diabetics. Archives in Cancer Research. 2017;05(01). Available from: https://doi.org/10.21767/2254-6081.1000134

[20] Arokiaraj MC, Menesson E. Novel anti-inflammatory and immunomodulation effects of rose on the endothelium in normal and hypoxic invitro conditions. Angiologia e Cirurgia Vascular. 2019;15(4):238-248. Available from: https://doi.org/10.48750/acv.221

[21] Laronha H, Caldeira J. Structure and function of human matrix metalloproteinases. Cells. 2020;9(5):1076. Available from: https://doi.org/10.3390/cells9051076

[22] Rybakowski JK. Matrix metalloproteinase-9 (MMP9) - a mediating enzyme in cardiovascular disease, cancer, and neuropsychiatric disorders. Cardiovascular Psychiatry and Neurology. 2009;2009:1-7. Available from: https://doi.org/10.1155/2009/904836

[23] Das A, Fanslow W, Cerretti D, Warren E, Talarico N, McGuire P. Angiopoietin/Tek interactions regulate MMP-9 expression and retinal neovascularization. Laboratory Investigation. 2003;83(11):1637-1645. Available from: https://doi.org/10.1097/01.LAB.0000097189.79233.D8

[24] Hollborn M, Stathopoulos C, Steffen A, Wiedemann P, Kohen L, Bringmann A. Positive feedback regulation between MMP-9 and VEGF in human RPE cells. Investigative Opthalmology \& Visual Science. 2007;48(9):4360. Available from: https://doi.org/10.1167/iovs.06-1234

[25] Valable S, Montaner J, Bellail A, Berezowski V, Brillault J, Cecchelli R, et al. VEGF-induced BBB permeability is associated with an MMP-9 activity increase in cerebral ischemia: both effects decreased by ANG-1. Journal of Cerebral Blood Flow \& Metabolism. 2005;25(11):1491-1504. Available from: https://doi.org/10.1038/sj.jcbfm.9600148

[26] Nowicki M, Wierzbowska A, Małachowski R, Robak T, Grzybowska-Izydorczyk O, Pluta A, et al. VEGF, ANGPT1, ANGPT2, and MMP-9 expression in the autologous hematopoietic stem cell transplantation and its impact on the time to engraftment. Annals of Hematology. 2017;96(12):2103-2112. Available from: https://doi.org/10.1007/s00277-017-3133-4

[27] Bergers G, Brekken R, McMahon G, Vu TH, Itoh T, Tamaki K, et al. Matrix metalloproteinase- 9 triggers the angiogenic switch during carcinogenesis. Nature
Cell Biology. 2000;2(10):737-744. Available from: https://doi.org/10.1038/35036374

[28] Johnson C, Sung H-J, Lessner SM, Fini ME, Galis ZS. Matrix metalloproteinase- 9 is required for adequate angiogenic revascularization of ischemic tissues. Circulation Research. 2004;94(2):262-268. Available from: https://doi.org/10.1161/01.RES.0000111527.42357.62

[29] Huang P-H, Chen Y-H, Wang C-H, Chen J-S, Tsai H$\mathrm{Y}$, Lin F-Y, et al. Matrix metalloproteinase-9 is essential for ischemia-induced neovascularization by modulating bone marrow-derived endothelial progenitor cells. Arteriosclerosis, Thrombosis, and Vascular Biology. 2009;29(8):1179-1184. Available from: https://doi.org/10.1161/ATVBAHA.109.189175

[30] Alawo DOA, Tahir TA, Fischer M, Bates DG, Amirova SR, Brindle NPJ. Regulation of Angiopoietin signalling by Soluble Tie2 ectodomain and engineered ligand trap. Scientific Reports. 2017;7(1). Available from: https://doi.org/10.1038/s41598-017-03981-6

[31] Balaji S, Han N, Moles C, Shaaban AF, Bollyky PL, Crombleholme TM, et al. Angiopoietin-1 improves endothelial progenitor cell-dependent neovascularization in diabetic wounds. Surgery. 2015;158(3):846-856. Available from: https://doi.org/10.1016/j.surg.2015.06.034

[32] Wang W, Li D, Xiang L, Lv M, Tao L, $\mathrm{Ni} \mathrm{T}$, et al. TIMP-2 inhibits metastasis and predicts prognosis of colorectal cancer via regulating MMP-9. Cell Adhesion \& $\mathrm{Mi}$ gration. 2019;13(1):272-283. Available from: https://doi.org/10.1080/19336918.2019.1639303

[33] Xu X, Zheng L, Yuan Q, Zhen G, Crane JL, Zhou X, et al. Transforming growth factor- $\beta$ in stem cells and tissue homeostasis. Bone Research. 2018;6(1):2. Available from: https://doi.org/10.1038/s41413-017-00054

[34] Zha Z, Bucher F, Nejatfard A, Zheng T, Zhang H, Yea $\mathrm{K}$, et al. Interferon- $\gamma$ is a master checkpoint regulator of cytokine-induced differentiation. Proceedings of the National Academy of Sciences. 2017;114(33):E6867-E6874. Available from: https://doi.org/10.1073/pnas.1706915114

[35] Singh S, Anshita D, Ravichandiran V. MCP-1: function, regulation, and involvement in disease. International Immunopharmacology. 2021;101:107598. Available from: https://doi.org/10.1016/j.intimp.2021.107598

[36] Sawant KV, Poluri KM, Dutta AK, Sepuru KM, Troshkina A, Garofalo RP, et al. Chemokine CXCL1 mediated neutrophil recruitment: role of glycosaminoglycan interactions. Scientific Reports. 2016;6(1):33123. Available from: https://doi.org/10.1038/srep33123 
[37] Azhar N, Namas RA, Almahmoud K, Zaaqoq A, Malak OA, Barclay D, et al. A putative "chemokine switch" that regulates systemic acute inflammation in humans. Scientific Reports. 2021;11(1):9703. Available from: https://doi.org/10.1038/s41598-02188936-8

[38] Knight BE, Kozlowski N, Havelin J, King T, Crocker SJ, Young EE, et al. TIMP-1 Attenuates the development of inflammatory pain through MMP-dependent and receptor-mediated cell signaling mechanisms. Frontiers in Molecular Neuroscience. 2019;12. Available from: https://doi.org/10.3389/fnmol.2019.00220

[39] Hirano T. IL-6 in inflammation, autoimmunity and cancer. International Immunology. 2020;33(3):127-148. Available from: https://doi.org/10.1093/intimm/dxaa078

[40] Ouyang W, O'Garra A. IL-10 family cytokines IL10 and IL-22: from basic science to clinical translation. Immunity. 2019;50(4):871-891. Available from: https://doi.org/10.1016/j.immuni.2019.03.020

[41] Di Paolo NC, Shayakhmetov DM. Interleukin $1 \alpha$ and the inflammatory process. Nature Immunology. 2016;17(8):906-913. Available from: https://doi.org/10.1038/ni.3503

[42] Scholz A, Plate KH, Reiss Y. Angiopoietin-2: a multifaceted cytokine that functions in both angiogenesis and inflammation. Annals of the New York Academy of Sciences. 2015;1347(1):45-51. Available from: https://doi.org/10.1111/nyas.12726

[43] Park SA, Jeong MS, Ha K-T, Jang SB. Structure and function of vascular endothelial growth factor and its receptor system. BMB Reports. 2018;51(2):73-78. Available from: https://doi.org/10.5483/BMBRep.2018.51.2.233

[44] Karagiannidis I, Jerman SJ, Jacenik D, Phinney BB, Yao R, Prossnitz ER, et al. G-CSF and G-CSFR modulate CD4 and CD8 T Cell responses to promote colon tumor growth and are potential therapeutic targets. Frontiers in Immunology. 2020;11. Available from: https://doi.org/10.3389/fimmu.2020.01885

[45] Li X, Liu R, Zhao Y, Gao N, Jin X, Gao X, et al. The extract from the roots of Rose odorata sweet var. gigantean (Coll. et Hemsl.) Rehd. et Wils attenuates DSS-induced ulcerative colitis by regulating the Nrf2/NF- $\kappa \mathrm{B}$ signaling pathways. RSC Advances. 2020;10(16):9450-9461. Available from: https://doi.org/10.1039/C9RA10747A

[46] Gruenwald J, Uebelhack R, Moré MI. Rosa canina Rose hip pharmacological ingredients and molecular mechanics counteracting osteoarthritis - a systematic review. Phytomedicine. 2019;60:152958. Available from: https://doi.org/10.1016/j.phymed.2019.152958

[47] Wu M, Feng H, Song J, Chen L, Xu Z, Xia W, et al. Structural elucidation and immunomodulatory activity of a neutral polysaccharide from the Kushui Rose (Rosa setate x Rosa rugosa) waste. Carbohydrate Polymers. 2020;232:115804. Available from: https://doi.org/10.1016/j.carbpol.2019.115804

[48] Al-Oqail MM, Farshori NN, Al-Sheddi ES, AlMassarani SM, Saquib Q, Siddiqui MA, et al. Oxidative stress mediated cytotoxicity, cell cycle arrest, and apoptosis induced by Rosa damascena in Human cervical cancer HeLa cells. Oxidative Medicine and Cellular Longevity. 2021;2021:1-11. Available from: https://doi.org/10.1155/2021/6695634

[49] Zhao L, Qiu J, Yin X, Zhang N, Wu W, Wang C, et al. Blossom and bee pollen from Rosa rugosa as potential intervention for acne caused by excessive androgen secretion in golden hamster acne model. Food and Agricultural Immunology. 2019;30(1):1174-1188. Available from: https://doi.org/10.1080/09540105.2019.1674788

[50] Firdous A, Sarwar S, Shah FA, Tabasum S, Zeb A, Nadeem $\mathrm{H}$, et al. Contribution of attenuation of TNF- $\alpha$ and NF- $\kappa$ B in the antiepileptic, anti-apoptotic and neuroprotective potential of Rosa webbiana fruit and its chitosan encapsulation. Molecules. 2021;26(8):2347. Available from: https://doi.org/10.3390/molecules26082347

[51] Wu M, Li W, Zhang Y, Shi L, Xu Z, Xia W, et al. Structure characteristics, hypoglycemic and immunomodulatory activities of pectic polysaccharides from Rosa setate x Rosa rugosa waste. Carbohydrate Polymers. 2021;253:117190. Available from: https://doi.org/10.1016/j.carbpol.2020.117190

[52] Kim K, Park Y, Jang H, Lee S, Lee S, Yun B, et al. Rugosic acid A, derived from Rosa rugosa Thunb., is novel inhibitory agent for NF- $\kappa$ B and IL6/STAT3 axis in acute lung injury model. Phytotherapy Research. 2020;34(12):3200-3210. Available from: https://doi.org/10.1002/ptr.6767

[53] Zhou S-F, Chen X-W. Inflammation, cytokines, the IL-17/IL-6/STAT3/NF- $\kappa$ B axis, and tumorigenesis. Drug Design, Development and Therapy. 2015;2015(9):2941-2946. Available from: https://doi.org/10.2147/DDDT.S86396

[54] Lee S-H, Choi S-H, Lee I-S, Kim Y, An E-J, Jang H-J. Anti-inflammatory effect of Rosa laevigata extract on in vitro and in vivo model of allergic asthma via the suppression of IgE and related cytokines. Molecular \& Cellular Toxicology. 2020;16(2):119-127. Available from: https://doi.org/10.1007/s13273-019-00063-8

Received: 2021-06-24

Revision Requested: 2021-09-27

Revision Received: 2021-11-26

Accepted: 2022-01-20 